\title{
L-arginine improves uterine spiral arterial wall thickness in mouse models of preeclampsia
}

\author{
Soetrisno*, Sri Sulistyowati*, and Anwar Sandi Wibowo*
}

\begin{abstract}
\section{BACKGROUND}

Preeclampsia is a major cause of maternal and fetal morbidity and mortality. The imbalance of anti-angiogenic and angiogenic factors plays a role in endothelial dysfunction in preeclampsia. L-arginine is expected to improve the process of spiral artery remodeling. This study aims to examine the use of L-arginine to repair endothelial damage by measuring the thickness of uterine spiral arteries in mouse (Mus musculus) models of preeclampsia.
\end{abstract}

\section{METHODS}

The researchers carried out an experimental study using 30 sixteen-day old pregnant Swiss mice (in good health, weighing 20-25 grams), which were randomly divided into 3 groups (each consisting of 10 mice). The groups were as follows: 1) normal pregnancy $\mathrm{K}(-) ; 2)$ preeclampsia model $\mathrm{K}(+)$; and 3) preeclampsia model receiving L-arginine (P). The authors performed histopathological examination of the mouse placenta, which had been dissected, embedded in paraffin wax and subsequently stained with hematoxylin and eosin (HE). The results were analyzed in SPSS v. 21 for Windows using Anova with Tukey.

\section{RESULTS}

The mean thickness of spiral arteries in group $\mathrm{K}(-)$ was $53.95+26.96$ $\mu \mathrm{m}$, in $\mathrm{K}(+) 96.50+16.66 \mu \mathrm{m}$, and in P $62.79+8.04 \mu \mathrm{m}$. Statistically, there were significant differences between groups $\mathrm{K}(-)$ and $\mathrm{K}(+)(\mathrm{p}=0.001)$ and between $\mathrm{K}(+)$ and $\mathrm{P}(\mathrm{p}=0.000)$, but non-significant differences between $\mathrm{K}(-)$ and $\mathrm{P}(\mathrm{p}=1.000)$.

\section{CONCLUSIONS}

The treatment with L-arginine proved to be effective in repairing endothelial damage by reducing intimal hyperplasia and atherosis and, in turn, the thickness of uterine spiral arteries in mouse models of preeclampsia.

Keywords: L-Arginine, spiral artery thickness, preeclampsia, mouse
*Department of Obstetrics and Gynecology, Faculty of Medicine, Sebelas Maret University/

Dr. Moewardi General Hospital Surakarta

Correspondence:

dr. Soetrisno, $\operatorname{SpOG}(\mathrm{K})$

J1. Slamet Riyadi No. 381 Surakarta

Phone : +62816672564

Email: soetrisno_spogk@yahoo.com

Date of first submission, May 29, 2017 Date of final revised submission, August 10, 2017

Date of acceptance, August 11, 2017

This open access article is distributed under a Creative Commons Attribution-

Non Commercial-Share Alike 4.0

International License

Cite this article as: Soetrisno, Sulistyowati S, Wibowo AS. L-arginine improves uterine spiral arterial wall thickness in mouse models of preeclampsia. Univ Med 2017;36: 131-7. doi: 10.18051/UnivMed.2017.v36.131137 


\section{INTRODUCTION}

Given the fact that the exact cause of preeclampsia remains unclear, its prevention in high-risk women is still unsatisfactory. Currently, preeclampsia is a major cause of high maternal and perinatal morbidity and mortality, especially in developing countries. Preeclampsia affects approximately $2-8 \%$ of all pregnant women around the world.(1) Hypertension, including preeclampsia, is being found in an increasing number of pregnant women and is becoming one of the most common medical complications in pregnancy. Approximately $70 \%$ of women diagnosed with hypertension are affected by preeclampsia. ${ }^{(2,3)}$ Complications of the disease cause about 50,000 maternal deaths each year. In developing countries, maternal mortality rates reach $15 \%$ compared to $0-1.8 \%$ in developed countries, due to limited access to maternal health care in the former. ${ }^{(4)}$ In Indonesia, the complications of preeclampsia account for approximately $30-40 \%$ of maternal deaths and about $30-50 \%$ of all perinatal deaths. In 2008 , there were 37 cases of preeclampsia (out of 1956 deliveries) in Dr. Moewardi General Hospital in Surakarta with the maternal mortality rate at about $67.6 \% .^{(5)}$

L-arginine is expected to play a role in preeclampsia prevention by relieving its systemic symptoms. ${ }^{(6,7)}$ The exact mechanism of Larginine in reducing and preventing the incidence of preeclampsia remains unknown. L-arginine allegedly improves the uterine spiral arteries' remodeling processes, which are impaired in preeclampsia. According to Ekambaram ${ }^{(8)}$ and Stuehr, ${ }^{(9)} \mathrm{L}$-arginine has a role in the pathway of L-arginine-nitric oxide. Impaired endothelium-dependent responses have been reported in isolated blood vessels of women with preeclampsia. ${ }^{(10,11)}$ This finding suggests that impaired production of endothelial nitric oxide (NO) may play an important role in mediating the pathophysiological process of preeclampsia. Given the ethical problems, it is impossible to conduct research using human uterus during the first trimester of pregnancy. In a rat model of preeclampsia, L-arginine, a substrate of NO synthase enzymes, was shown to decrease blood pressure. ${ }^{(12)}$ Human data are controversial as far as the efficacy of L-arginine supplementation in ameliorating hypertension in pregnancy is concerned. A study of randomized placebocontrolled design has demonstrated that a short term IV infusion of L-arginine can significantly reduce blood pressure. ${ }^{(13)}$ Other placebo controlled trials have not shown an improvement in blood pressure with oral L-arginine supplementation, ${ }^{(14)}$ but suggest an improvement in fetal outcomes. ${ }^{(15)}$

In the present research, the authors decided to investigate the abovementioned problem in the laboratory mouse (Mus musculus) because of its ability to adapt to the laboratory environment as well as its genetic resemblance to humans, which can be used as a comparison of preeclampsia in human pregnancies. This study aims to evaluate the effect of L-arginine to repair the damage of endothelial spiral arteries that undergo intima tunica hyperplasia and atherosis in a mouse model of preeclampsia.

\section{METHODS}

\section{Research design}

An experimental study, based on post-test control group design, conducted at the Faculty of Veterinary Medicine, Airlangga University, Surabaya from November 2016 to January 2017.

\section{Research subjects}

The researchers carried out the study using 30 sixteen-day old pregnant Swiss mice, which were randomly divided into 3 groups (each consisting of 10 mice). The groups were as follows: normal pregnancy $\mathrm{K}(-)$; preeclampsia model $\mathrm{K}(+)$; and preeclampsia model receiving L-arginine $(\mathrm{P})$. The laboratory technicians performed histopathological examination of the mouse placenta, which had been dissected, embedded in paraffin wax and subsequently stained with hematoxylin and eosin (HE). The 
researchers' goal was to examine differences in histopathological findings in uterine spiral arteries and subsequently compare the results in these groups. The inclusion criteria were as follows: animals in good health; 3 months old, and weighing approx. 20-25 grams. The exclusion criterion was death of an animal during the research. The mice (Mus musculus, Swiss strain) were obtained from Pusat Veterinaria Farma in Surabaya.

\section{Experimental treatments}

At the beginning of the study, the researchers synchronized the estrus of all female mice by injecting them with $5 \mathrm{IU}$ pregnant mare serum gonadotropin (PMSG). After 48 hours, the researchers injected them with 5 IU human chorionic gonadotropin (HCG), and then mated the mice with male mice $(7$ months old and weighing approx. 60 grams). The diagnosis of pregnancy was expected about 17 hours after mating with the presence of copulatory plugs.

The researchers injected the $\mathrm{K}(+)$ and $(\mathrm{P})$ groups with $10 \mathrm{ng}$ of anti-Qa2 intraperitoneally (IP) from the first day until the $4^{\text {th }}$ day of pregnancy in order to establish preeclampsia models in accordance with the method designed by Sulistyowati et al. ${ }^{(16)}$ Furthermore, the (P) group was given L-arginine $200 \mathrm{mg} / \mathrm{kgBW} /$ day orally using a gastric tube, on days 7-15 of pregnancy.

\section{Preparation of the placental tissue}

On the $16^{\text {th }}$ day of pregnancy, the researchers performed dissection in the three groups in order to examine placental tissue samples, which were embedded in paraffin wax, stained with hematoxylin eosin (HE), and viewed under the microscope at $400 \mathrm{x}$ magnification. The reason for dissection and the preparation of slides on the $16^{\text {th }}$ day of pregnancy is that this is assumed to correspond to the second trimester of pregnancy in humans, where the manifestations of preeclampsia arise. The assessed parameter was the thickness of the spiral artery walls (in micrometers, $\mu \mathrm{m}$ ).

\section{Data analysis}

The results of the research have been analysed in SPSS v. 21 for Windows using MannWhitney test with a significance level of 0.05 (confidence interval 95\%).

\section{Ethical clearance}

The study has been approved by the research ethics commission of the Faculty of Veterinary Medicine, Airlangga University, Surabaya (Ref. no. 648-KE).

\section{RESULTS}

The core tunica spiral artery thickness in normal pregnant mouse group $\mathrm{K}(-)$ was less than that in the preeclampsia model $\mathrm{K}(+)$. Furthermore, the researchers found out that the spiral artery thickness was reduced whereas its diameter was increased in the preclampsia model (P), which received L-arginine treatment, in comparison to the preeclampsia model group $\mathrm{K}(+)$ (Figures 1$3)$.

The mean thickness of the spiral artery wall in group $\mathrm{K}(+)$ is $(96.50 \pm 16.66 \mu \mathrm{m})$, higher than in the preeclampsia group $\mathrm{P}(62.79 \pm 8.04 \mu \mathrm{m})$ and group $\mathrm{K}(-)(53.95 \pm 26.96 \mu \mathrm{m})$. The ANOVA test result shows a significant difference in the mean thickness of the spiral artery wall in the three groups ( $p=0.001$ ). Based on the result of Tukey's multiple comparison test, it is shown that the mean thickness of the spiral artery wall in group $\mathrm{K}(+)$ is significantly different from group $\mathrm{K}(-)$ $(p=0.024)$ and from the preeclampsia group $P$ $(p=0.004)$. The mean thickness of the spiral artery wall in group $\mathrm{K}(-)$ is not different from the preeclampsia group $\mathrm{P}(\mathrm{p}=0.062)$ (Table 1).

\section{DISCUSSION}

In preeclampsia, placental hypoperfusion results in severe stenosis and occlusion of the spiral arteries which affect the syncytial node of the placenta and lead to increased numbers of cytotrophoblasts; changes to the villous vascularization; calcification; obliterating 


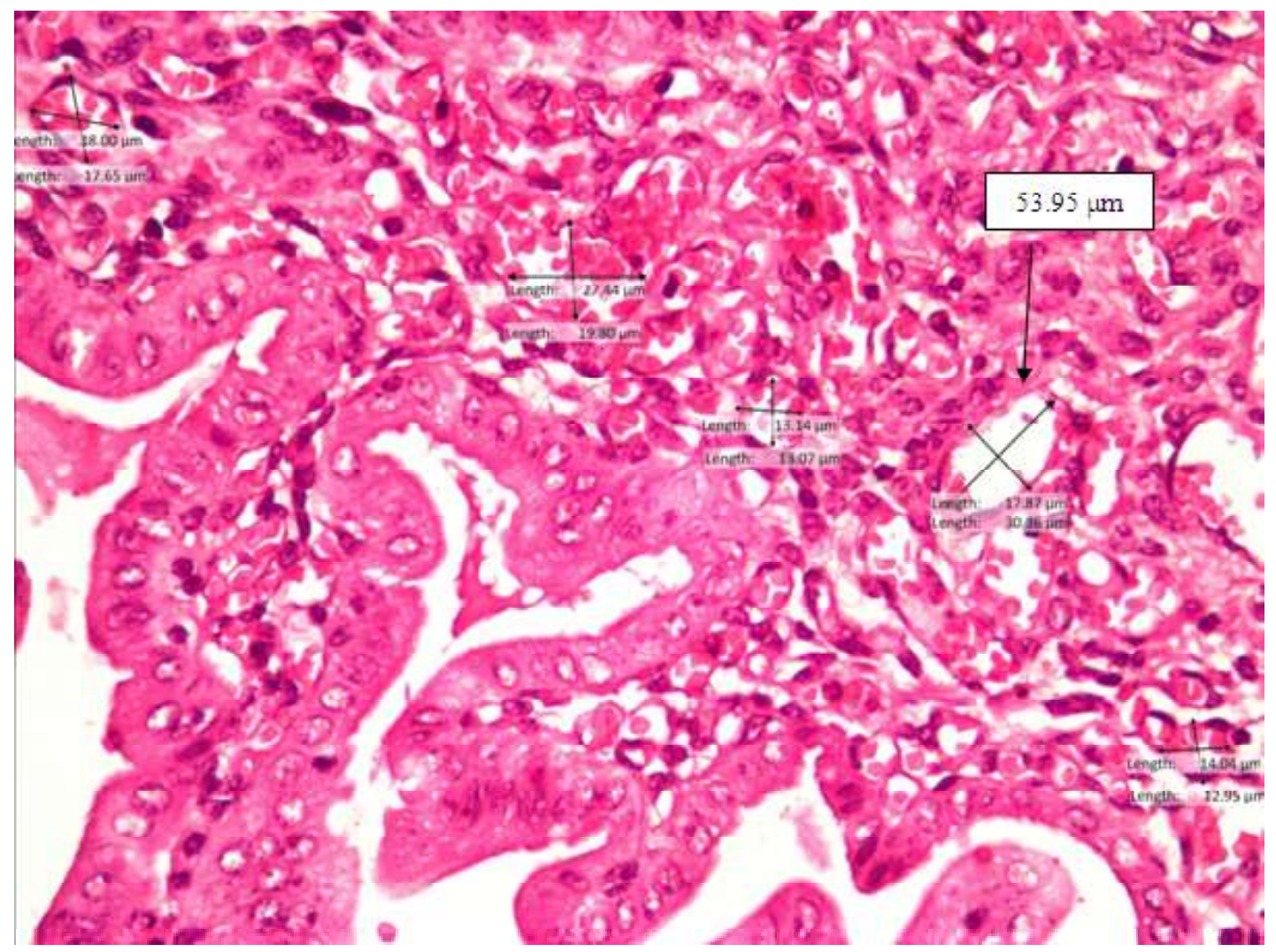

Figure 1. Spiral artery in normal pregnant mice K(-)

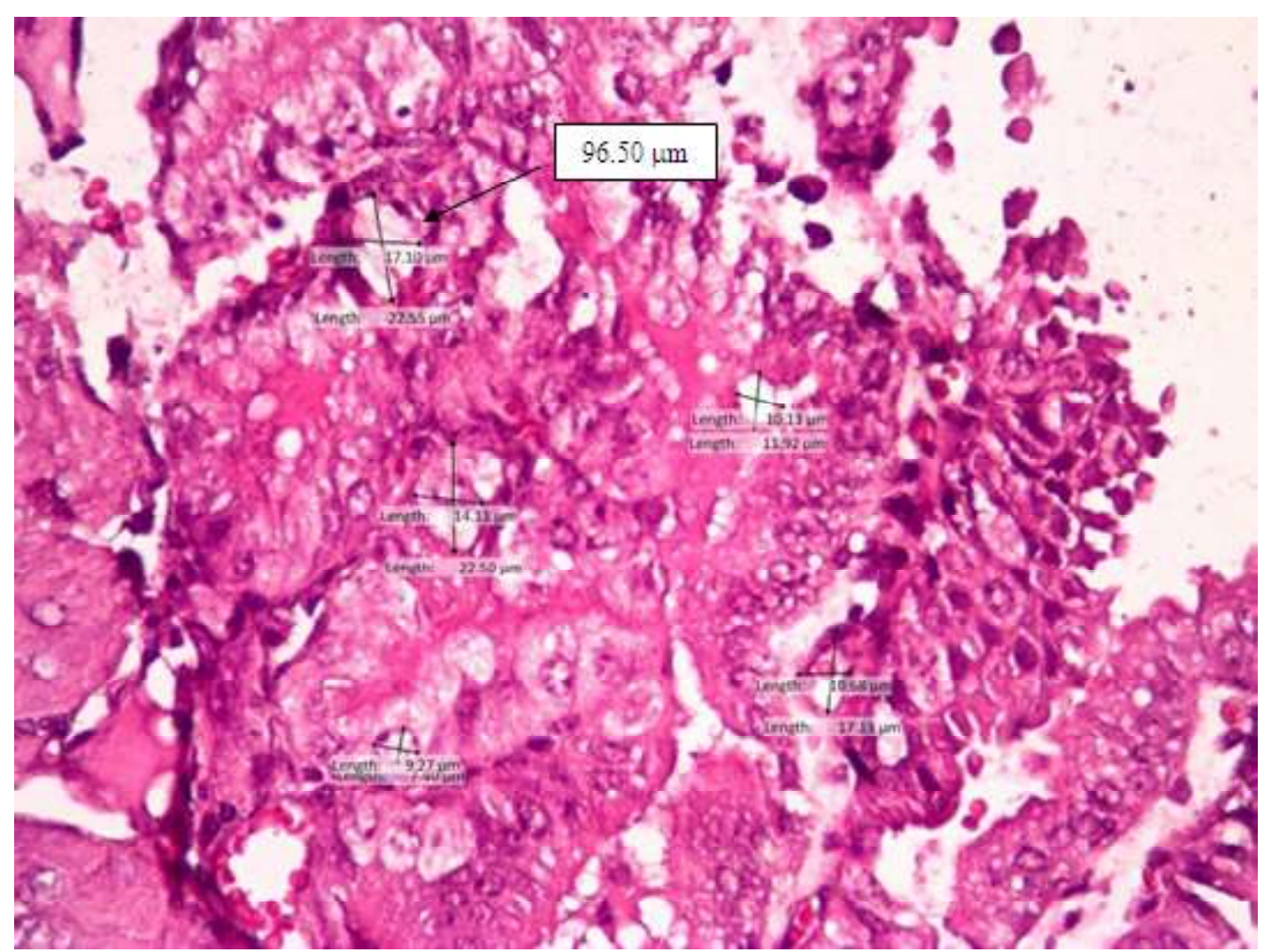

Figure 2. Spiral artery in mice of control group $\mathrm{K}(+)$ 


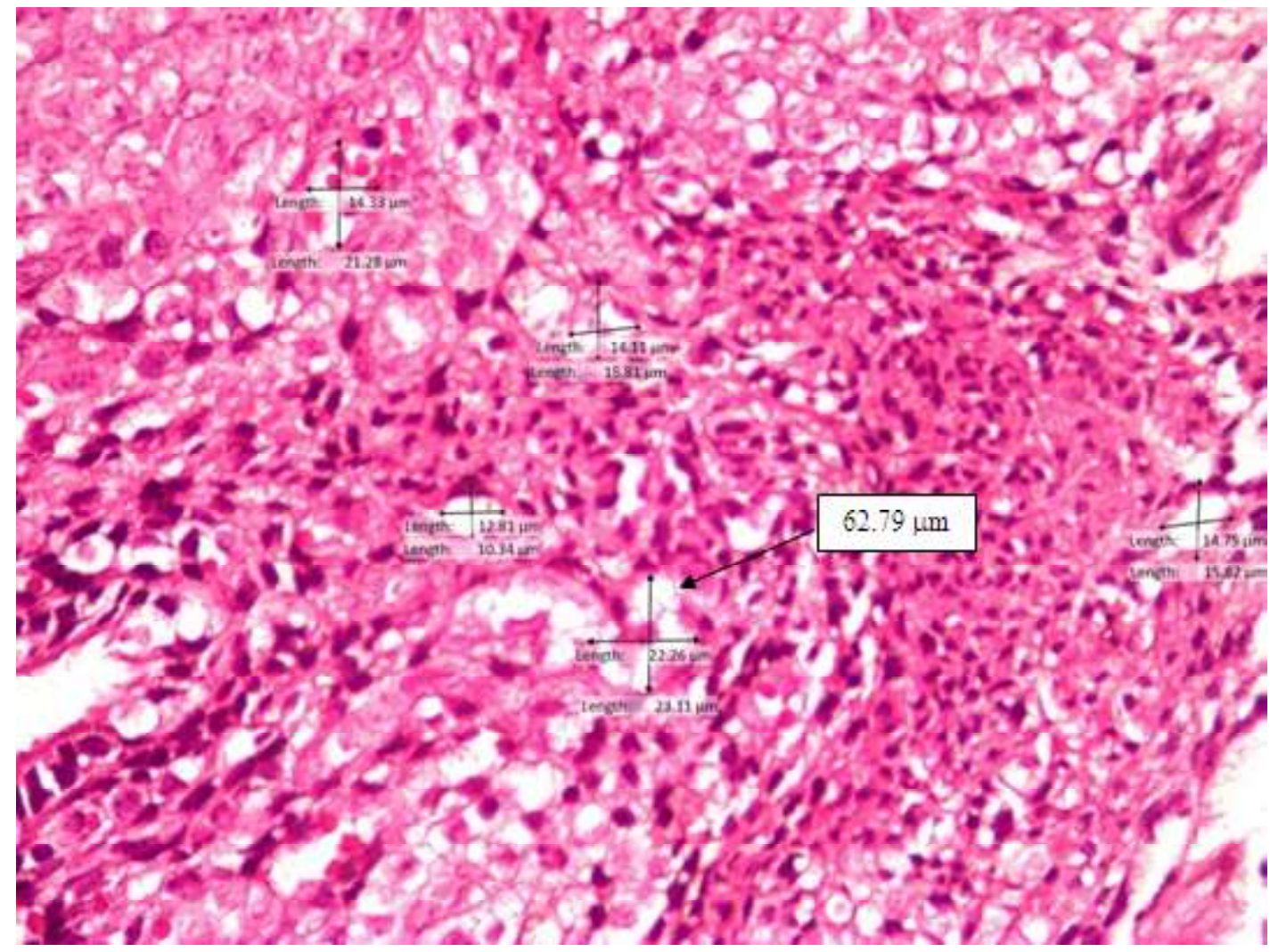

Figure 3. Spiral artery in mice of treated group (P)

endarteritis, atherosis, infarction, thrombosis and necrosis. Blood vessel abnormalities affect blood flow in preeclampsia because spiral arteries are the arteries that supply the intervillous space. Reduced blood flow in the intervillous space causes hypoxia, which can lead to obliterating endarteritis due to reduced supply of oxygen to the blood vessels, especially the arterioles. Consequently, the smooth muscle cells of the tunica media migrate to the tunica intima and undergo a proliferation characterized by thickening of the tunica intima and, in turn, narrowing of the blood vessels. ${ }^{(17)}$

In this research, the mean spiral artery thickness in the preeclampsia mouse model group was greater than normal and less than in the group treated with L-arginine, with the differences being statistically significant. However, there was no significant difference in the spiral artery thickness in normal pregnancies compared to the preeclampsia group treated with L-arginine, which means that the L-arginine treatment was effective in reducing the spiral artery thickness and increasing its diameter.

L-arginine acts as a precursor of nitric oxide and is converted to nitric oxide (NO) and Lcitrulline by nitric oxide synthase (NOS) and can prevent the occurrence of preeclampsia. A study showed that dietary supplementation with a combination of L-arginine and antioxidants was associated with a significant reduction in the incidence of preeclampsia, compared with

Table 1. Mean spiral artery thickness by treatment groups

\begin{tabular}{lcccc}
\hline & \multicolumn{3}{c}{ Treatment groups } & \multirow{2}{*}{ p value } \\
\cline { 2 - 4 } & $\mathbf{K}(-)(\mathbf{n}=\mathbf{1 0})$ & $\mathbf{K}(+)(\mathbf{n}=\mathbf{1 0})$ & $\mathbf{P}(\mathbf{n}=\mathbf{1 0})$ & \\
\hline Spiral artery thickness $(\mu \mathrm{m})$ & $53.95 \pm 26.96$ & $96.50 \pm 16.66$ & $62.79 \pm 8.04$ & 0.001 \\
\hline
\end{tabular}

$\mathrm{K}(-)=$ normal; $\mathrm{K}(+)=$ preeclampsia; $\mathrm{P}=$ preeclampsia $+\mathrm{L}$-arginine 
antioxidants alone and with placebo. ${ }^{(18,19)}$ Given that L-arginine is widely available as a dietary supplement, L-arginine can be viewed as potential therapy to prevent preeclampsia. ${ }^{(2,20,21)}$

According to the studies conducted by Han et al. ${ }^{(22)}$ and $\mathrm{Li}$ et al., ${ }^{(23)}$ the concentration of Larginine is significantly reduced in women with pre-eclampsia compared to normal pregnancies. Studies on animal models show that the Larginine-NO system undergoes dysregulation during pregnancy. ${ }^{(24,25)}$ Hypertension, proteinuria, intra-uterine growth restriction (IUGR) and glomerular damage may occur due to inhibition of NO synthesis. Therefore, hypertension caused by inhibition of NO synthesis may be treated by supplementation with L-arginine. ${ }^{(26,27)}$ Furthermore, given the fact that oxidative stress may play a key role in the development of endothelial dysfunction and preeclampsia in human pregnancies, the administration of Larginine may improve uteroplacental circulation and reduce maternal blood pressure. ${ }^{(4,22,28)}$

However, this study had limitations such as the blood pressure and urinary protein of the test animals could not be determined due to lack of equipment. Therefore, the preeclamptic state of the mice was determined based on the instructions listed in the report of Sulistyowati et al. ${ }^{(16)} \mathrm{L}$ arginine has been found to be a potentially novel therapy for hypertension in pregnancy in order to prevent the incidence of preeclampsia in women at high risk for the disease. It is suggested that further research are conducted on the use of Larginine in women at high risk for preeclampsia.

\section{CONCLUSIONS}

The research has proved that L-arginine is effective in repairing endothelial damage by reducing the thickness of the uterine spiral arteries and, in turn, tunica intima hyperplasia and atherosis in a mouse model of preeclampsia. Larginine may become a new treatment option for hypertension in pregnancy and the prevention of preeclampsia in high-risk women.

\section{CONFLICT OF INTEREST}

The authors declare that there is no conflict of interest associated with this study, the authors, and/ or the publication of this article.

\section{ACKNOWLEDGMENTS}

The researchers would like to thank to the staff members of the Faculty of Veterinary Medicine of Airlangga University, Surabaya, for the mating of the mice to get them pregnant, preparation of the mouse models of preeclampsia, and care of the pregnant mice until research sampling and preparation. Thanks also to the Anatomical Pathology laboratory of the Faculty of Veterinary Medicine of Airlangga University, Surabaya, who made the paraffin-embedded samples and performed histopathological observation on the research sample.

\section{CONTRIBUTORS}

S participated in drafting the manuscript and write up. SS and SW participated in the conception and design of the study, data collection, analysis and interpretations of the findings. All authors read and approved the final manuscript.

\section{REFERENCES}

1. World Health Organization. WHO recommendations for prevention and treatment of pre-eclampsia and eclampsia. Geneva: World Health Organisation;2011.

2. Burke SD, Karumanchi SA. Spiral artery remodelling in preeclampsia revisited. Hypertension 2013;62:1013-4.

3. Camacho E, Silva JA, Matos MG, et al. Actividad de las enzimas anti oxidantes en el rinon de la rata con preeclampsia experimental. ArchivosVen Farmacol Ter 2011;30:44-50.

4. Creasy RK, Resnik R, Iams JD, et al. Editors. Maternal-fetal medicine: principles and practice. 7th ed. Philadelphia, PA: Saunders;2014.

5. Cunningham FG, Leveno KJ, Bloom SL, et al. Editors. William obstetrics. $24^{\text {th }}$ ed. New York: McGraw Hill Education;2014. 
6. Al-Bayati MA, Ahmad MA, Khamas W. The potential effect of L-arginine on mice placenta. Adv Pharmacoepidemiol Drug Saf 2014;3:150. doi: 10.4172/2167-1052.1000150.

7. Dorniak-Wall T, Grivell RM, Dekker GA, et al. The role of $\mathrm{L}$-arginine in the prevention and treatment of pre-eclampsia: a systematic review of randomized trials. J Hum Hypertens 2014;28:2305. doi: 10.1038/jhh.2013.100.

8. Ekambaram P. HSP70 expression and its role in preeclamptic stress. Indian J Biochem Biophys 2011;48:243-55.

9. Stuehr DJ. Enzymes of the L-arginine to nitric oxide pathway. J Nutr 2004;134:2748S-51S.

10. George EM, Granger JP. Recent insights into the pathophysiology of preeclampsia. Expert Rev Obstet Gynecol 2010;5:557-66. doi: 10.1586/ eog.10.45.

11. Ghulmiyyah L, Sibai B. Maternal mortality from preeclampsia/eclampsia. Semin Perinatol 2012;36:56-9. doi: 10.1053/j.semperi.2011.09.011.

12. Alexander BT, Llinas MT, Kruckeberg WC, et al. $\mathrm{L}$-arginine attenuates hypertension in pregnant rats with reduced uterine perfusion pressure. Hypertension 2004;43:832-6. doi: 10.1161/ 01.HYP.0000119192.32360.a9.

13. Neri I, Jasonni VM, Gori GF, et al. Effect of Larginine on blood pressure in pregnancy-induced hypertension: a randomized placebo-controlled trial. J Matern Fetal Neonatal Med 2006;19:27781. doi: 10.1080/14767050600587983.

14. Staff AC, Berge L, Haugen G, et al. Dietary supplementation with L-arginine or placebo in women with preeclampsia. Acta Obstet Gynecol Scand 2004;83:103-7.

15. Rytlewski K, Olszanecki R, Lauterbach R, et al. Effects of oral L-arginine on the foetal condition and neonatal outcome in preeclampsia: a preliminary report. Basic Clin Pharmacol Toxicol 2006;99:146-52. doi: 10.1111/j.1742-7843. 2006.pto_468.x.

16. Sulistyowati S, Bachnas MA, Anggraini ND, et al. Recombinant vascular endothelial growth factor 121 injection for the prevention of fetal growth restriction in a preeclampsia mouse model. J Perinat Med 2017;45:245-51. doi: 10.1515/jpm-2016-0149.

17. Simbolon SE, Durry M, Lintong P. Gambaran histopatologi plasenta pada kehamilan dengan preeklampsia. Ebiomedik 2013;1:1069-74.
18. Gilbert JS, Babcock SA, Granger JP. Hypertension produced by reduced uterine perfusion in pregnant rats is associated with increased soluble fms-like tyrosine kinase-1 expression. Hypertension 2007;50:1142-7. doi: 10.1161/ HYPERTENSIONAHA.107.096594.

19. Hagmann H, Thadhani R, Benzing T, et al. The promise of angiogenic markers for the early diagnosis and prediction of preeclampsia. Clin Chem 2012;58:837-45. doi: 10.1373/clinchem. 2011.169094.

20. Masuyama H, Nobumoto E, Segawa T, et al. Severe superimposed preeclampsia with obesity, diabetes, and mild imbalance of angiogenic factors. Acta Med Okayama 2012;66:171-5.

21. Kim JY, Kim YM. Acute atherosis of the uterine spiral arteries: clinicopathologic implications. J Pathol Transl Med 2015;49:462-71. doi: 10.4132/ jptm.2015.10.23.

22. Han L, Yang Z, Li K, at al. Antepartum or immediate postpartum renal biopsies in preeclampsia/eclampsia of pregnancy: new morphologic and clinical findings. Int J Clin Exp Pathol 2014;7:5129-43.

23. Li Z, Zhang Y, Ying MJ, et al. Recombinant vascular endothelial growth factor 121 attenuates hypertension and improves kidney damage in a rat model of preeclampsia. Hypertension 2017;50:686-92. doi: 10.1161/HYPERTENSION AHA.107.092098.

24. Lukito JS, Dewi P. Gambaran histopatologi arteria spiralis alas plasenta pada preeklampsia / klampsia dan kehamilan normotensif. Majalah Kedokteran Nusantara 2007;40:173-9.

25. Playfair JH, Chain BM. Immunology at a glance. $9^{\text {th }}$ ed. New Jersey: Wiley-Blackwell;2009.

26. Powe CE, Levine RJ, Karumachi SA. Preeclampsia, a disease of the maternal endothelium: the role of antiangiogenic factors and implications for later cardiovascular disease. Circulation 2011;123: 2856-69. doi: 10.1161/CIRCULATIONAHA. 109.853127.

27. Pribadi A, Mose JC, Anwar AD. Patogenesis preeklampsia \& manifestasi gejala klinis dalam kehamilan risiko tinggi perkembangan, implikasi \& kontroversi. Mataram: Sagung Seto; 2015.

28. Roberts JM, Hubel CA. The two stage model of preeclampsia: variation on the theme. Placenta 2009;30 Suppl A:S32-S7. doi: 10.1016/j.placenta. 2008.11.009. 